\section{INTERNAL FUNCTIONING \\ OF ROMANIAN NON-PROFIT \\ ORGANIZATIONS - A NEW \\ GOVERNANCE MODEL AND \\ ITS EFFECT ON SERVICES \\ AND COMMUNITY RELATIONS}

\section{Claudia PETRESCU}

Martin BALOGH

\section{Natalia Monica BALOGH}

\section{Paula BEUDEAN}

\section{Claudia PETRESCU \\ Professor, Dean of Graduated Education, \\ Oakland University, Rochester Hills, Michigan, U.S.A. \\ E-mail: cpetrescu@oakland.edu}

\section{Martin BALOGH}

Associate Professor, Public Administration and

Management Department, Faculty of Political,

Administrative and Communication Sciences,

Babeș-Bolyai University, Cluj-Napoca, Romania

Tel.: 0040-264-431.361

E-mail: marton@fspac.ro

\section{Natalia Monica BALOGH}

Lecturer, Public Administration and Management Department,

Faculty of Political, Administrative and Communication Sciences,

Babeș-Bolyai University, Cluj-Napoca, Romania

Tel.: 0040-264-431.361

E-mail: natalia@fspac.ro

\section{Paula BEUDEAN}

Ph.D. Candidate, Political Sciences Department, Faculty of Political, Administrative and Communication Sciences, Babeș-Bolyai University, Cluj-Napoca, Romania

E-mail: beudean@fspac.ro
DOI:10.24193/tras.60E.5

Published First Online: 2020/06/22

\begin{abstract}
The Romanian non-profit sector is experiencing an explosive growth, an increase of $60 \%$ in the last ten years due to the rapid economic and political changes taking place in the region. Currently, there are over 100,000 non-profits with approximately $40 \%$ of them being active (FDSC, 2017). This exploratory research aims to provide an understanding of the current Romanian non-profit governance model, the balance of power between board members and the executive director, and their implication on organizational relations with the community. The research analyzes the board - executive relation in the current social-economic context and the board's involvement in the organization. The study also looks at how these affect the relations of the organizations with the community. Finally, the paper also analyzes how the financing model impacts the Romanian non-profit governance model. An online capacity-building assessment was used to collect the data. It was administered in the period August - October 2015 (for 55 active non-profit organizations with a $66 \%$ response rate).
\end{abstract}

Keywords: Romanian non-profit organizations, governance model, community relations. 


\section{Introduction}

The main funding sources for the over 42,000 active Romanian non-profits (FDSC, 2017) are the very competitive public funds offered by public grant-makers (governmental or European Union funds) and international funders (FDSC, 2017). Philanthropy in Romania is weak, being at an early stage of development. Hence, the competition for funds has increased after EU integration compared to before the integration when EU funds were strategically directed towards the Romanian non-profit sector. Lacking a developed philanthropic Romanian society, we see an increasing dependency of non-profits over EU funds and Romanian governmental resources. This dependency impacts the management of the organizations including the human resources and service delivery functions (FDSC and USAID, 2014). These challenges are expected to influence the governance model of the Romanian non-profit sector, shape the roles of the board and executive directors (ED) and the balance of power between them.

Even though the size and the dynamics of the Romanian non-profit sector cannot yet be compared with the traditional non-profit sectors from other European countries, still there is an upward trend (Barna, 2014) both in quantitative (number of organizations) and qualitative (involvement in diverse societal issues) aspects, a trend that can bring significant change in the way in which the sector functions and further develops.

There is no recent peer-reviewed literature addressing the issue of governance in the Romanian non-profit sector, but these challenges, especially the financial ones, are expected to impact the way strategic decisions are made in organizations, thus these need to be addressed by academia. The Romanian non-profit sector adopted the Western NGO leadership model (Board of Directors and Executive Director) but this has been continuously adapted to the Romanian context. The goals of the research are to understand how the Romanian non-profit sector adapts the Western leadership model, respectively to understand the current Romanian non-profit governance model and the balance of power between board members and the executive director, and their impact on non-profit organizations' relationship with the community.

A pre-tested capacity building assessment instrument (Petrescu and Clifford, 20092011) was used for this study. The instrument measures the capacity of non-profit organizations in five areas: (a) leadership development, (b) organizational development, (c) program development, (d) collaboration and community engagement, and (e) program evaluation. The instrument was translated into Romanian and adapted to the characteristics of the Romanian non-profit sector. It was administered online through Survey Monkey in August - October 2015. The survey was taken by 55 organizations. We obtained a $66 \%$ response rate.

To achieve our research goals, we analyzed data referring to three capacity development areas: leadership development, organizational development, and collaboration and community engagement. 


\section{The non-profit governance model in Romania - legislation and practice}

The activity of the Romanian non-profit organizations - associations and foundations - was for the very first time regulated, through dedicated legislation, in 1924. However, during the communist regime, these organizations were banned. After the 1989 anti-communist revolution, new legislation was designed for the re-emerging civil society. It was approved by the Parliament in 2005.

The governance model, proposed by the current legislation (the Governmental Decree no. 26/2000, approved by Law no. 246/2005), includes different governance provisions for each non-profit form (association and foundation). The Association is run by the General Assembly (GA), which has the responsibility of establishing the strategy and the objectives of the organization, and to approve the annual budget and the profit and loss accounts. The board of directors, appointed by the GA, has an executive role. It is responsible for proposing and executing the annual budget, for reporting the association's activities and the profit and loss accounts to the GA, deciding on the association's personnel structure, and legally representing the organization. Moreover, the board of directors can empower one or multiple persons to take on these executive responsibilities - usually, this person is the President of the association (however, this position and responsibilities are not mentioned in the legislation).

A foundation is run by a board of directors. The foundation board has similar responsibilities with the GA of an association. It establishes the goal and the objectives of the foundation, the strategy and the programs, approves the annual budget and the profit and loss accounts. It executes the budget, decides on the personnel structure, and legally represents the organization. The current legislation does not mention the executive director (ED) position and his/her responsibilities, the structure of the organization being decided by the board of directors.

There is no peer-reviewed literature on the Romanian governance model for non-profits. At the moment, the knowledge about how the Romanian non-profits are governed is available through studies and reports published by relevant non-profits, such as FDSC (Fundația pentru Dezvoltarea Societății Civile/The Foundation for the Civil Society Development). The 2017 FDSC report about the Romanian non-governmental sector (the previous one was published in 2010) looked at two governance issues: the decision-making process and the strategic planning tools used by Romanian non-profits (FDSC, 2017, p. 61).

The 2017 FDSC report shows that 34\% of the Romanian non-profits are governed through decisions made by the Executive Director or the President, $30 \%$ of them through decisions made by the Board, and $20 \%$ - through decisions made by the Board together with the ED (the rest, $16 \%$ of the organizations, are ruled through the GA's decisions) (FDSC, 2017, p. 61). The decisions are people-oriented and less process-oriented. This means that the decisions are mainly made in accordance with the wishes of the most experienced people in the Board or the ED, where experience refers to knowledge or expertise or the number of years dedicated to the organization (FDSC, 
2017, p. 62). In regard to this decision-making style, the study shows that in organizations that have been for at least eight years on the market, the ED/President is rarely changed: $63 \%$ of the associations are run by presidents holding this position for more than 8 years. In the other $18 \%$ of the organizations, the presidents have been running now the organization for 4 to 8 years. $60 \%$ of the foundations have executive directors holding this position for more than 8 years and $16 \%$ of them have EDs that have been holding this position for 4 to 8 years.

The same study found that the employees are consulted more for decisions regarding project implementation and less regarding organizational issues. The clients are even less involved in the decision-making process: they are being asked for opinions or feedback only on issues related to the services they access (FDSC, 2017, p. 62).

Regarding strategic planning, the same report shows that $54 \%$ of the Romanian non-profits acknowledge that they have a strategic plan in place and that $25 \%$ have a fundraising strategy (FDSC, 2017, p. 63). However, for most of the non-profits (small and medium organizations), the strategic plan is more a survival strategy and not a development strategy. Only large organizations can afford to develop a strategic plan that follows the organization's mission and which includes clear objectives for the development of new programs or services (FDSC, 2017, pp. 63-64).

Our research builds on the FDSC's work and takes it further by looking deeper into the non-profit organizations' decision-making. The purpose of this paper is to understand how the governance model currently works, how the power relation between the Board and the ED is defined, how the board's roles are assumed, and how the governance model affects the organization - community relationships.

\section{Research methodology}

A capacity-building assessment instrument created and tested as part of a Capacity Building grant received by Petrescu and Clifford (2009-2011) was used for this study. The instrument measures the capacity of non-profit organizations in five areas: (a) leadership development, (b) organizational development, (c) program development, (d) collaboration and community engagement, and (e) program evaluation. The instrument was translated into Romanian and adapted to the characteristics of the Romanian non-profit sector. In order to understand the differences between the US and Romanian non-profit sectors, interviews with five executive directors of non-profit organizations were conducted in the summer of 2014. These executives were provided during the interview with a translation of the survey and worked with the researchers to adapt the instrument to the characteristics of the Romanian non-profit sector. The revised survey was administered online through Survey Monkey in August - October 2015.

The Romanian research team identified 55 active non-profit organizations that were then invited to take the survey. Being a pilot study in the field of the governance model of Romanian NGOs, the organizations were identified in the network of the research team, which is also actively involved in the Romanian non-profit sector for more than 15 years, using the convenience sampling method, and identifying or- 
ganizations that could be considered representative for the sector, in terms of size, services provided, diversity of resources and governance structure. With 33 organizations responding, we have a return rate of $66 \%$. The survey was sent to at least two senior-level managers in each organization. We received one response per organization. The respondent organizations are from all geographical areas of Romania. The Nord-Western and Central Regions are better represented among the respondents, as these regions (besides Bucharest, the capital) have the highest density of non-profit organizations in the country.

As the differences regarding the roles of the board of directors of associations and those of foundations are very small, through this paper, we use the title board of directors (the Board) for the top leadership structure for both types of organizations. When we talk about the highest executive position in these organizations, we use only the Executive Director (ED) term, even if this position might also be President/Administrative Director/Manager, etc.

Using the capacity-building assessment instrument (Petrescu and Clifford, 20092011), we look at how the pre-defined roles of the Board, by the Romanian legislation, are assumed by the de facto governance model, and we will learn more about the ED's roles and about the power balance between the two leadership positions. Thus, we will analyze the following aspects: strategic planning process in the organization, leadership and decision-making process, financial responsibilities and annual budgeting, and community relations. We asked the respondents to tell us, on a scale from 1 to 4 , how the organization performs regarding various organizational practices ( $4=$ we do this very well; $1=$ does not apply to us). The performance scale illustrates the areas in which organizations master various practices or still have work to do to improve their practices.

\section{Characteristics of the respondents}

The Romanian non-profit sector began its revival and development after the 1989 revolution. Few organizations revived the parent organization that existed prior to World War II. We had among our respondents one such organization that provided the answer '1924' to the question 'When were you established?'. The other organizations are young, as expected: eight $(25 \%)$ were established right after the revolution (1990-1999), 17 (53\%) between 2000-2009, and six (19\%) since 2010.

The organizations vary in size in terms of staff, board, and volunteers.

Staff size:

Out of the 29 that provided this information, we have:

- $5(17 \%)$ with no staff;

- 12 (41\%) with less than 10 staff members;

- 6 (21\%) with 11-20 staff members;

- 5 (17\%) with 21-50 staff members; and

- one with over 50 staff members. 
The size of the board is what we expected to find in an emerging civil society. 29 organizations shared with us the size of their boards:

- 12 organizations $(41 \%)$ have less than 5 members;

- 16 organizations (55\%) have 5-8 members;

- One organization has more than 8 members.

In terms of volunteers, we see that the phenomena of volunteering took roots and it is strongly developing. 27 organizations answered the question:

- 17 organizations $(63 \%)$ have less than 25 volunteers;

- $2(7 \%)$ - between $26-49$;

- $2(7 \%)$ - between $5-100$;

- $6(22 \%)$ have over 100 volunteers;

To understand the size of the respondents from a budgetary perspective, we faced some challenges. Some organizations did not provide information about their budgets (one said that it is 'secret'), others provided it into Romanian currency, or euro, or dollars; others just provided a number without the type of currency they referred to. Most of them said 'approximately' this much. The (approximate) budget provided into euro and dollars was converted into Romanian currency (the leu/RON) using the currency rate available on November 14, 2015. Based on this information, we had among our respondents:

- 10 organizations with budgets under 1 million lei $(€ 220,000)$;

- 12 organizations with budgets between 1 million and 10 million lei ( $€ 2.2$ million);

- two organizations with budgets over $€ 2.2$ million.

29 organizations provided information about how their budget evolved in the last five years. For 24 organizations (83\%), the budget increased.

In regard to the main funding sources, we see that these are diverse (Figure 1) with public funds playing an important role. $62 \%$ of these organizations have one or two funding sources, and only $10 \%$ have five or more than five funding sources.

It is important to note that the budget of these organizations might not be representative of all Romanian non-profits. Out of all the approximately 100,000 organizations that form the non-profit sector, most of them have small budgets $-80 \%$ of Romanian non-profits have annual budgets smaller than $€ 2,000$ (FDSC, 2014, p. 33).

\section{Findings regarding strategic planning}

$90 \%$ of the 29 organizations that provided information about their strategic planning process said they have a strategic plan for the next 3-5 years (see Table 1 for detailed information). The rationale for having a strategic plan varies: for $59 \%$ of the organizations the Board asked for one, while in the rest of the cases, the respondents said that nobody asked for it (31\%) or that the main funder/funders requested it (10\%). However, $58 \%$ of the organizations are not completely satisfied with the long-term goals and annual objectives included in the plan. $42 \%$ said that they are not happy 


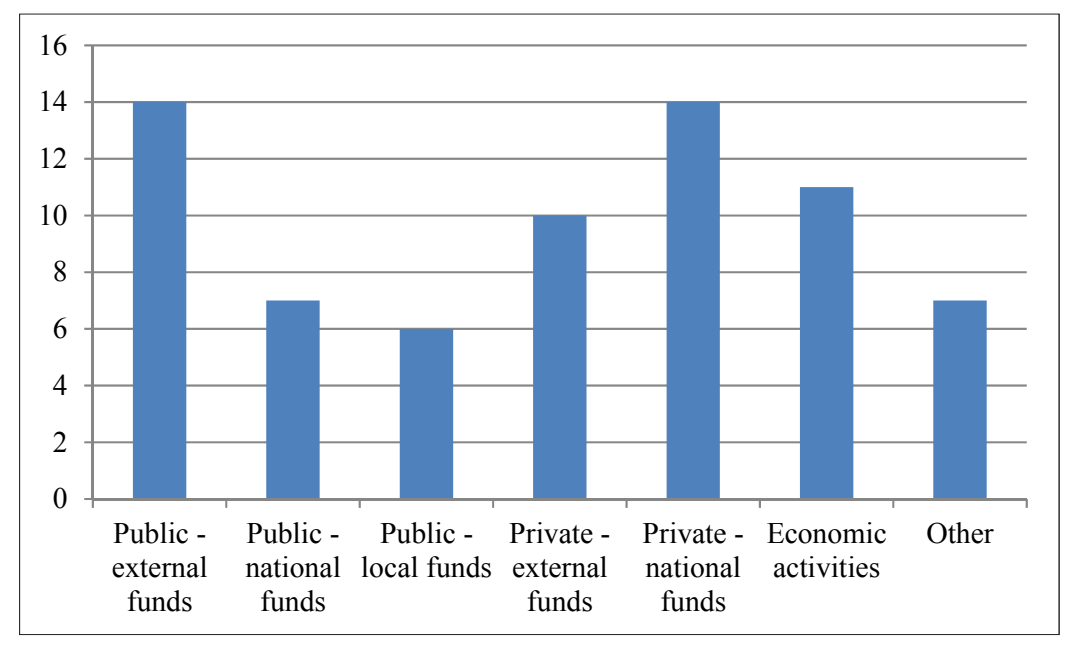

Figure 1: Number of organizations' funding sources

Source: Our own survey data

with how the approval process of the plan happens, and in the case of $17 \%$ of organizations the Board was not involved in the approval process of the plan. $80 \%$ of the organizations are not satisfied with how the ED monitors the strategic goals and objectives of the organization, and $76 \%$ are not satisfied with how the ED evaluates the strategic plan towards the organization's results and performance. At the same time, in average, two-thirds of the organizations show deficiencies in involving relevant stakeholders (staff, volunteers, donors, funders, clients) in gathering information for the development of the strategic plan; and only $19 \%$ of the organizations are doing very well in using the evaluation results of the previous programs in developing the strategic plan. These findings indicate that, while strategic plans exist, their function and use are still uncertain within the organizations. The Board needs to play a stronger role in shaping strategic thinking in the organization. The ED needs to use more the strategic plan in steering the organization. The communication between non-profits and stakeholders is weak in developing strategic plans.

\section{Findings regarding leadership and decision-making}

The majority of the organizations $(52 \%)$ consider that the Board does very well in following the organization's bylaws, but in only $20 \%$ of the organizations the Board assumes an active role of establishing the organization's future priorities (see Table 2 for detailed information). The data indicates that there is a synergy between the Board and ED: in $63 \%$ of cases, the Board is comfortable making decisions based on the ED's recommendations, and in $57 \%$ of the organizations, the ED works very well together with the Board in deciding the future priorities of the organization.

This process can be related to the data referring to how well-informed the board is and how it communicates with the ED and the management team - in both issues, 
Table 1: Strategic planning issues

\begin{tabular}{|c|c|c|c|c|c|c|}
\hline \multirow{2}{*}{$\begin{array}{l}\text { Strategic planning: } \\
\text { organizational practices }\end{array}$} & \multirow{2}{*}{$\begin{array}{l}\text { Total } \\
\text { respondents }\end{array}$} & \multicolumn{5}{|c|}{ Performance level (\% respondents) } \\
\hline & & $\begin{array}{l}\text { We do this } \\
\text { very well }\end{array}$ & $\begin{array}{l}\text { We should do } \\
\text { this better }\end{array}$ & $\begin{array}{l}\text { We don't do it } \\
\text { but we should }\end{array}$ & $\begin{array}{l}\text { Does not } \\
\text { apply to us }\end{array}$ & $\begin{array}{l}\text { I do not } \\
\text { know }\end{array}$ \\
\hline $\begin{array}{l}\text { The strategic plan includes } \\
\text { long-term goals and annual } \\
\text { objectives }\end{array}$ & 26 & $34 \%$ & $50 \%$ & $8 \%$ & $4 \%$ & $4 \%$ \\
\hline $\begin{array}{l}\text { The Board approved } \\
\text { the strategic plan }\end{array}$ & 26 & $42 \%$ & $27 \%$ & $15 \%$ & $12 \%$ & $4 \%$ \\
\hline $\begin{array}{l}\text { The ED monitors constantly } \\
\text { the goals and the objectives } \\
\text { from the strategic plan }\end{array}$ & 25 & $12 \%$ & $72 \%$ & $8 \%$ & $8 \%$ & $0 \%$ \\
\hline $\begin{array}{l}\text { The ED monitors constantly } \\
\text { if the strategic plan brings } \\
\text { the wanted results }\end{array}$ & 25 & $16 \%$ & $68 \%$ & $8 \%$ & $8 \%$ & $0 \%$ \\
\hline $\begin{array}{l}\text { The strategic plan takes } \\
\text { into consideration previous } \\
\text { programs' evaluation }\end{array}$ & 26 & $19 \%$ & $50 \%$ & $27 \%$ & $4 \%$ & $0 \%$ \\
\hline $\begin{array}{l}\text { The strategic plan takes } \\
\text { into consideration information } \\
\text { from volunteers, staff and } \\
\text { board members }\end{array}$ & 26 & $38 \%$ & $54 \%$ & $8 \%$ & $0 \%$ & $0 \%$ \\
\hline $\begin{array}{l}\text { The strategic plan takes } \\
\text { into consideration information } \\
\text { from donors and funders }\end{array}$ & 26 & $15 \%$ & $62 \%$ & $8 \%$ & $15 \%$ & $0 \%$ \\
\hline $\begin{array}{l}\text { The strategic plan takes } \\
\text { into consideration information } \\
\text { from clients }\end{array}$ & 26 & $19 \%$ & $65 \%$ & $16 \%$ & $0 \%$ & $0 \%$ \\
\hline
\end{tabular}

Source: Our own survey data

the organizations are facing difficulties in being outstanding in these processes. At the same time, it is worth highlighting that $46 \%$ of the organizations indicate that the assertion 'Board establishes alone the priorities of the organization' does not apply to them, even though this responsibility is clearly stipulated in the Romanian non-profit legislation, as the main job of the Board. Also, 'Does not apply to us' rate is higher than usual for the issues of the Board's involvement in ED recruitment, his/her job description and salary - so the organizations do not perceive these issues as being the Board's responsibilities. This aspect is a clear deviation from the Western model in which the Board is actively involved in defining the ED's role, in his/her recruitment, and establishing the ED's salary.

Moreover, even if the Board recruits and selects the ED, it seems that the Board lacks authority over the ED, as most of the organizations are not satisfied with how the Board establishes the salary of the ED, how it writes the ED's job description, how it establishes the annual performance objectives and how it evaluates the ED against 
these. Few organizations (13\%) indicate that the Board is doing a very good job at mentoring the ED, and only $22 \%$ do a very good job in governing the organization by establishing the ED's annual objectives.

Table 2: Leadership and decision-making

\begin{tabular}{|c|c|c|c|c|c|c|}
\hline \multirow{2}{*}{$\begin{array}{l}\text { Leadership \& decision-making: } \\
\text { organizational practices }\end{array}$} & \multirow{2}{*}{$\begin{array}{l}\text { Total } \\
\text { respondents }\end{array}$} & \multicolumn{5}{|c|}{ Performance level (\% respondents) } \\
\hline & & $\begin{array}{l}\text { We do this } \\
\text { very well }\end{array}$ & $\begin{array}{l}\text { We should do } \\
\text { this better }\end{array}$ & $\begin{array}{l}\text { We don't do it } \\
\text { but we should }\end{array}$ & $\begin{array}{l}\text { Does not } \\
\text { apply to us }\end{array}$ & $\begin{array}{l}\text { I do not } \\
\text { know }\end{array}$ \\
\hline $\begin{array}{l}\text { The Board respects their } \\
\text { roles from the bylaws }\end{array}$ & 24 & $52 \%$ & $44 \%$ & $4 \%$ & $0 \%$ & $0 \%$ \\
\hline $\begin{array}{l}\text { The Board helps in recruiting } \\
\text { new board members }\end{array}$ & 24 & $25 \%$ & $33 \%$ & $33 \%$ & $9 \%$ & $0 \%$ \\
\hline $\begin{array}{l}\text { The Board has efficient discus- } \\
\text { sions and makes fast decisions }\end{array}$ & 24 & $33 \%$ & $46 \%$ & $9 \%$ & $8 \%$ & $4 \%$ \\
\hline $\begin{array}{l}\text { All the Board members are } \\
\text { up-to-date with the information } \\
\text { about the organizations }\end{array}$ & 24 & $29 \%$ & $58 \%$ & $9 \%$ & $0 \%$ & $4 \%$ \\
\hline $\begin{array}{l}\text { The Board is comfortable } \\
\text { to make decisions based on } \\
\text { the ED's recommendations }\end{array}$ & 24 & $63 \%$ & $29 \%$ & $4 \%$ & $0 \%$ & $4 \%$ \\
\hline $\begin{array}{l}\text { The Board communicates con- } \\
\text { stantly and efficiently with the } \\
\text { ED and the management team }\end{array}$ & 24 & $29 \%$ & $58 \%$ & $9 \%$ & $0 \%$ & $4 \%$ \\
\hline $\begin{array}{l}\text { The Board decides alone the } \\
\text { organization's future priorities }\end{array}$ & 24 & $20 \%$ & $17 \%$ & $13 \%$ & $46 \%$ & $4 \%$ \\
\hline $\begin{array}{l}\text { The Board decides together } \\
\text { with the ED the organization's } \\
\text { future priorities }\end{array}$ & 23 & $57 \%$ & $35 \%$ & $4 \%$ & $0 \%$ & $4 \%$ \\
\hline $\begin{array}{l}\text { The Board writes } \\
\text { the ED job description }\end{array}$ & 24 & $25 \%$ & $42 \%$ & $4 \%$ & $21 \%$ & $8 \%$ \\
\hline $\begin{array}{l}\text { The Board recruits } \\
\text { and selects the ED }\end{array}$ & 24 & $50 \%$ & $17 \%$ & $4 \%$ & $25 \%$ & $4 \%$ \\
\hline $\begin{array}{l}\text { The Board establishes } \\
\text { the ED's salary }\end{array}$ & 23 & $39 \%$ & $31 \%$ & $4 \%$ & $22 \%$ & $4 \%$ \\
\hline $\begin{array}{l}\text { The Board is informed about } \\
\text { the ED's priorities and decisions }\end{array}$ & 23 & $57 \%$ & $30 \%$ & $9 \%$ & $0 \%$ & $4 \%$ \\
\hline $\begin{array}{l}\text { When it is needed, } \\
\text { the Board helps the ED in } \\
\text { the decision-making process }\end{array}$ & 23 & $35 \%$ & $52 \%$ & $9 \%$ & $0 \%$ & $4 \%$ \\
\hline $\begin{array}{l}\text { The Board establishes ED's } \\
\text { annual performance objectives } \\
\text { and evaluates his/her results }\end{array}$ & 23 & $22 \%$ & $39 \%$ & $26 \%$ & $4 \%$ & $9 \%$ \\
\hline $\begin{array}{l}\text { The organization provides a } \\
\text { mentoring program to the ED }\end{array}$ & 24 & $13 \%$ & $29 \%$ & $38 \%$ & $17 \%$ & $3 \%$ \\
\hline
\end{tabular}

Source: Our own survey data 


\section{Findings regarding financial responsibilities and annual budgeting}

The findings on financial responsibilities, including fundraising, and on annual budgeting indicate that the ED has better control over the organization's money than the Board. $48 \%$ of respondents indicate that the ED makes all decisions regarding financial commitments versus $28 \%$ of organizations that say the same thing about the Board. The findings indicate that the Board has a weaker position regarding financial decisions and responsibilities: organizations do not involve well enough the Board in making financial decisions, in monitoring the restricted funds, and in discussing and analyzing the annual budget (see Table 3 for detailed information).

At the same time, the Board lacks authority over the financial issues, as the ED seems to poorly involve the Board in financial decisions or in fundraising activities. Along this line, there can be observed the high unusual rates for 'Does not apply to us' answer for questions regarding the Board's role in monitoring funds, budgets and fundraising results. Again, the organizations do not seem to believe that these are the board of directors' responsibilities.

Moreover, very few organizations are satisfied with the board's involvement in fundraising and the board members' connections with funders or philanthropists. Also, it is worth mentioning that the organizations are doing better in establishing projects' budgets than organizational annual budgets.

Table 3: Financial issues and annual budgeting

\begin{tabular}{|c|c|c|c|c|c|c|}
\hline \multirow{2}{*}{$\begin{array}{l}\text { Financial issues } \\
\text { and annual budgeting: } \\
\text { organizational practices }\end{array}$} & \multirow{2}{*}{$\begin{array}{l}\text { Total } \\
\text { respondents }\end{array}$} & \multicolumn{5}{|c|}{ Performance level (\% respondents) } \\
\hline & & $\begin{array}{l}\text { We do this } \\
\text { very well }\end{array}$ & $\begin{array}{l}\text { We should do } \\
\text { this better }\end{array}$ & $\begin{array}{l}\text { We don't do it } \\
\text { but we should }\end{array}$ & $\begin{array}{l}\text { Does not } \\
\text { apply to us }\end{array}$ & $\begin{array}{l}\text { I do not } \\
\text { know }\end{array}$ \\
\hline $\begin{array}{l}\text { There is an annual budget } \\
\text { for the organization }\end{array}$ & 25 & $44 \%$ & $44 \%$ & $12 \%$ & $0 \%$ & $0 \%$ \\
\hline $\begin{array}{l}\text { There is a separate budget } \\
\text { for each project }\end{array}$ & 25 & $60 \%$ & $28 \%$ & $8 \%$ & $4 \%$ & $0 \%$ \\
\hline $\begin{array}{l}\text { The Board analyses and dis- } \\
\text { cusses the annual budget }\end{array}$ & 25 & $20 \%$ & $36 \%$ & $32 \%$ & $12 \%$ & $0 \%$ \\
\hline $\begin{array}{l}\text { The ED consults periodically } \\
\text { the Board on financial issues }\end{array}$ & 25 & $28 \%$ & $44 \%$ & $12 \%$ & $12 \%$ & $4 \%$ \\
\hline $\begin{array}{l}\text { The Board makes all the de- } \\
\text { cisions in regard to relevant } \\
\text { financial commitments }\end{array}$ & 25 & $28 \%$ & $40 \%$ & $0 \%$ & $32 \%$ & $\%$ \\
\hline $\begin{array}{l}\text { The ED makes all the decisions } \\
\text { in regard to relevant financial } \\
\text { commitments }\end{array}$ & 25 & $48 \%$ & $28 \%$ & $0 \%$ & $24 \%$ & $0 \%$ \\
\hline $\begin{array}{l}\text { The ED monitors how the } \\
\text { restricted funds are used }\end{array}$ & 25 & $56 \%$ & $32 \%$ & $8 \%$ & $4 \%$ & $0 \%$ \\
\hline $\begin{array}{l}\text { The Board monitors how } \\
\text { the restricted funds are used }\end{array}$ & 25 & $16 \%$ & $28 \%$ & $12 \%$ & $36 \%$ & $8 \%$ \\
\hline
\end{tabular}




\begin{tabular}{|c|c|c|c|c|c|c|}
\hline \multirow{2}{*}{$\begin{array}{l}\text { Financial issues } \\
\text { and annual budgeting: } \\
\text { organizational practices }\end{array}$} & \multirow{2}{*}{$\begin{array}{c}\text { Total } \\
\text { respondents }\end{array}$} & \multicolumn{5}{|c|}{ Performance level (\% respondents) } \\
\hline & & $\begin{array}{l}\text { We do this } \\
\text { very well }\end{array}$ & $\begin{array}{l}\text { We should do } \\
\text { this better }\end{array}$ & $\begin{array}{l}\text { We don't do it } \\
\text { but we should }\end{array}$ & $\begin{array}{l}\text { Does not } \\
\text { apply to us }\end{array}$ & $\begin{array}{l}\text { I do not } \\
\text { know }\end{array}$ \\
\hline $\begin{array}{l}\text { The Board is involved in } \\
\text { prospecting new donors }\end{array}$ & 24 & $17 \%$ & $29 \%$ & $42 \%$ & $8 \%$ & $4 \%$ \\
\hline $\begin{array}{l}\text { The Board is involved in fund- } \\
\text { raising campaigns and events }\end{array}$ & 25 & $8 \%$ & $44 \%$ & $36 \%$ & $12 \%$ & $0 \%$ \\
\hline $\begin{array}{l}\text { The Board monitors } \\
\text { the fundraising results }\end{array}$ & 25 & $12 \%$ & $32 \%$ & $32 \%$ & $24 \%$ & $0 \%$ \\
\hline $\begin{array}{l}\text { The Board closely cooperates } \\
\text { with the ED in fundraising } \\
\text { activities }\end{array}$ & 25 & $16 \%$ & $24 \%$ & $40 \%$ & $12 \%$ & $8 \%$ \\
\hline $\begin{array}{l}\text { The Board has good connec- } \\
\text { tions with funders, donors or } \\
\text { philanthropists }\end{array}$ & 25 & $16 \%$ & $28 \%$ & $28 \%$ & $24 \%$ & $4 \%$ \\
\hline
\end{tabular}

Source: Our own survey data

\section{Findings regarding organization-community relationship}

Regarding the organizations' relationship with the community, as it is illustrated in Table 4, there are many areas for improvement, from research on community needs, to participation in community meetings or to consultation with funders to understand better the target groups' needs. The results show that the organizations are project-oriented in regard to the community relations they establish: almost two-thirds of the organizations are doing very well in establishing strategic partnerships with other organizations for specific projects, but very few of them are outstanding in evaluating these partnerships. It is important to note that we have zero 'Does not apply to us' answers to the questions about organizational practices in this area. This is a strong indicator that non-profits are mindful of their community. While many practices can be improved, organizations are making efforts to involve the community and to develop partnerships with community members and other non-profit organizations.

\section{Discussion of findings}

The governance model of Romanian non-profits, designed by the sector's specific legislation, gives to the Board full power for the organization on strategic planning issues (determining organizations' priorities, strategies, programs), on the financial issues (annual budget, profit and loss accounts) and on the organization's relations with third parties. However, our research shows that the Romanian non-profit organizations function differently than the law suggests: the Board's and other stakeholders' involvement in the strategic planning process is poorly done; the Board is barely involved (and some organizations do not even consider it necessary) in the financial decisions, in fundraising and in monitoring the financial results of the organization; and the relations with the community are mainly project-oriented. Our research results 
Table 4: Community relations

\begin{tabular}{|c|c|c|c|c|c|c|}
\hline \multirow{2}{*}{$\begin{array}{l}\text { Community relations: } \\
\text { organizational practices }\end{array}$} & \multirow{2}{*}{$\begin{array}{l}\text { Total } \\
\text { respondents }\end{array}$} & \multicolumn{5}{|c|}{ Performance level (\% respondents) } \\
\hline & & $\begin{array}{l}\text { We do this } \\
\text { very well }\end{array}$ & $\begin{array}{l}\text { We should do } \\
\text { this better }\end{array}$ & $\begin{array}{l}\text { We don't do it } \\
\text { but we should }\end{array}$ & $\begin{array}{l}\text { Does not } \\
\text { apply to us }\end{array}$ & $\begin{array}{c}\text { I do not } \\
\text { know }\end{array}$ \\
\hline $\begin{array}{l}\text { The organization researches } \\
\text { and analyzes constantly the } \\
\text { community needs and clients' } \\
\text { needs to develop new programs } \\
\text { and services }\end{array}$ & 24 & $29 \%$ & $67 \%$ & $4 \%$ & $0 \%$ & $0 \%$ \\
\hline $\begin{array}{l}\text { The organization consults the } \\
\text { community leaders and with } \\
\text { funders on the target group's } \\
\text { needs }\end{array}$ & 24 & $29 \%$ & $71 \%$ & $0 \%$ & $0 \%$ & $0 \%$ \\
\hline $\begin{array}{l}\text { The staff or the Board members } \\
\text { participate in community meet- } \\
\text { ings to collect information on } \\
\text { community needs and priorities }\end{array}$ & 24 & $29 \%$ & $67 \%$ & $4 \%$ & $0 \%$ & $0 \%$ \\
\hline $\begin{array}{l}\text { The staff or the Board members } \\
\text { participate in community meet- } \\
\text { ings to identify potential future } \\
\text { partners }\end{array}$ & 24 & $29 \%$ & $71 \%$ & $0 \%$ & $0 \%$ & $0 \%$ \\
\hline $\begin{array}{l}\text { The organization develops } \\
\text { strategic partnerships with } \\
\text { other organizations for specific } \\
\text { projects }\end{array}$ & 24 & $67 \%$ & $25 \%$ & $8 \%$ & $0 \%$ & $0 \%$ \\
\hline $\begin{array}{l}\text { The organization evaluates the } \\
\text { partnerships once per year }\end{array}$ & 24 & $33 \%$ & $50 \%$ & $17 \%$ & $0 \%$ & $0 \%$ \\
\hline
\end{tabular}

Source: Our own survey data

show that the executive director has low interest in following the strategic plan of the organization; that he/she has significant power over the organization's money and resources; he/she has a strong influence over the Board's decisions or he/she takes the responsibility of making important decisions alone; and finally, he/she is poorly monitored and evaluated by the Board for his/her tasks, payment and performance.

At the same time, the findings support the FDSC study's conclusions regarding the two governance issues: strategic planning and decision-making process. The FDSC report shows that the majority of the non-profits have mainly survival strategies instead of development strategies. Our research provides data supporting the idea that non-profits use strategic planning for developing survival plans, as the organizations are not satisfied with how the goals and long-term objectives are established in the plan, and how these are then monitored by the executive director. This might be suggesting that the plan and its monitoring are part of a formal process requested by the Board or by the main funder and that the ED might be caught in day-to-day survival activities. However, this could also be the sign of a gap in leadership. We found that neither the Board nor the ED assumes thoroughly the responsibility for developing 
a real and relevant strategic plan for the organization. This might be a result of the fact that the non-profit organizations are run in a project-based manner, with a high interest in following the projects' goals and objectives, and less time or interest in following the overall organization's goals and objectives.

Regarding the decision-making process, our study supports FDSC's results that most of the organizational decisions are made by the Board together with the ED/the President or alone by the ED/President. Our research results show that the board is counting on the executive director's recommendations when it has to make decisions, and also the executive director has more authority on making decisions on important financial commitments, restricted funds, fundraising, organizational priorities, etc. At the same time, our research shows that many organizations do not even consider that some of the leadership roles, traditionally assumed by the Board, could be part of the Board members' job descriptions. This data can be correlated with FDSC's findings on the EDs' longevity in their positions and the decision-making style (people-oriented) - the ED usually holds this position for more years than the Board members, thus he/ she might be considered more entitled to make the most important organizational decisions than the Board members.

Our research also provides some starting information regarding organizations' working style. Looking at how the organizations do in terms of annual budget versus projects' budgets and at how the organizations establish partnerships with other organizations (project-based), we can further test the idea that the organizations' work is project-oriented. They seem to put more emphasis on projects' objectives and goals, projects' budgets, projects' indicators and results than on the organizations' priorities, objectives, budgets and overall results.

\section{References:}

1. Barna, C., Atlasul Economiei Sociale. România 2014 (Atlas of the Social Economy. Romania 2014), Bucharest: Institutul de Economie Socială, 2014.

2. Fundația pentru Dezvoltarea Societății Civile (FDSC) and USAID, Indexul sustenabilității organizațiilor societății civile 2013 - România (Sustainability Index of Civil Society Organizations 2013 - Romania), Bucharest: FDSC, 2014.

3. Fundația pentru Dezvoltarea Societății Civile (FDSC) (Foundation for the Development of Civil Society), România 2010. Sectorul neguvernamental. Profil, tendinte, provocări (Romania 2010. The Non-Governmental Sector. Profile, Trends, Challenges), Bucharest: FDSC, 2010.

4. Fundația pentru Dezvoltarea Societății Civile (FDSC), România 2017. Sectorul Neguvernamental. Profil, Tendinte, Provocări (Romania 2017. The Non-Governmental Sector. Profile, Trends, Challenges), Bucharest: FDSC, 2017.

5. Governmental Decree no. 26/2000 regarding associations and foundations (approved through Law no. 246/2005), published in the Official Journal of Romania no. 39 of January 31, 2000. 